the scientific honours heaped upon him made not the slightest difference to his modest and unassuming manner and address. He was a man who can never have had an enemy and who has left an abiding mark in the memory of his innumerable friends.

Cherwell.

The late Sir William Bragg's wide influence upon contemporary science is universally acknowledged. It was always his desire that men of science should throw aside the cloak of mysticism and seclusion and appear as other men striving after truth in no matter what field of action. This view has recently acquired especial significance because of the great service to the State which science, when properly applied, is now generally seen to be capable of giving ; and it was this attitude of mind that largely prompted his delight in simplifying, so far as possible, for the benefit of others many of the highly complex problems of physics with which his name is so closely connected. Thus his lectures were remarkable for their clarity and experimental illustration. The underlying motive was always to let others see and understand what his own clear vision could discover.

The Royal Institution afforded ideal facilities for research and exposition, which exactly suited Bragg's temperament. $\mathrm{He}$ showed in many ways how deeply he felt the honour and responsibility of following in the footsteps of Faraday. Sir William's versatility was particularly noticeable in the courses of Christmas Lectures to Children, which he delivered in 1919-20 upon "Sound", since it was then that his interest in music suggested many ingenious illustrations. For the series he gave in 1931-32 he chose "Light" as the subject and dealt fully with the nature of colour and colour mixtures. In this connexion it may be pointed out that during the last meeting of the British Association at Cambridge, an exhibition of pictures by members was arranged, and there Sir William showed several charming water-colour landscapes which he had painted when abroad. His Christmas Lectures were memorable occasions for many reasons, beca,use the presence of children always stimulated in him those fascinating qualities of friendliness and enthusiasm which were a dominating characteristic of his nature. His quick mind often enabled him to make a witty reply to a question, but it never wounded.

After each of the Christmas lectures there were delightful tea parties in Sir William's private rooms.

We, at the Royal Institution, deplore the loss of one whose guidance in all affairs was so invaluable and fair-minded. We cherish the memory of his invariable courtesy, kindliness, enthusiasm and loyalty to the great traditions of his calling. $\mathrm{He}$ was beloved by all.

Charles E. S. Philuips.

(Hon. Sec. Royal Institution.)

Is the death of Sir William Bragg we lose a great man and well-tried friend; and, distinguished as have been his services to science and to the State, it is the sense of personal loss, the tribute to his rich human qualities, which now dominates. The loss was so completely unexpected; age had not withered him ; his wide and generous knowledge was ready to hand and at the service of all real inquirers; his interests were as fresh as ever, and his unique power of lucid exposition seemed to grow greater as time passed this tract on electromagnetism, which saw the light but a month or two since, is a model of its kind).

His pioneer contributions to physical science have provided a probe for the scrutiny of the submicroscopic world and, equally with these investigations, his faculty for seizing on essentials, for reducing a complex problem to its simplest elements, for describ. ing physical phenomena with incomparable clarity and charm, made him a most fitting head of an institution the traditions of which are so intimately associated with the names of Davy and of Faraday.

A little incident comes to mind which may serve to illustrate these qualities. A paper was read before one of our societies by a young investigator who, with the blundering particularity of youth, insisted on describing methods and results with such indiscriminating zeal and detail, that his audience was left completely befogged. Perfunctory applause had died down, when Sir William rose, and in a five-minute speech gave a masterly sketch of the paper, which showed it for the sound piece of work that it was, cleared the mists from the minds of his hearers, and left the author heartened and encouraged.

Friendliness and helpfulness were of the essence of his being; and though institutions may remain, while those who direct their activities come and go, it is difficult to think of the Royal Institution without Sir William's friendly presence, guiding and leading the researches of the laboratory and informing the work of the Institution with the spirit of Faraday.

May his memory long be kept green !

\section{Allan Ferguson.}

Tночgh it was a great pleasure to meet Sir William Bragg anywhere and on any occasion, it is on his own ground at the Royal Institution that most of us best remember him. The setting so became him ; and he so graced the setting. Whether receiving the guests on a Friday evening, or expounding some of the mysteries of science in the great lecture theatre, or merely entertaining some stray scientific visitor to tea, Bragg had the art, which was no art because it was rooted in real interest and a genuine affection for humanity, of making the visitor foel at home. Any scientific society which might have been fortunate enough to obtain the privilege of holding a meeting in the Institution would usually find on arrival that the Director, by some happy chance, had business which took him into the entrance hall, and the visitors would receive from him friendly informal greetings which made them feel that they were not intruders, but welcome guests. In the work and welfare of the younger generation of men of science Bragg's interest was almost paternal.

In his early work Bragg made some fundamental contributions to the science of radioactivity. $\mathrm{He}$ was, I believe, the first to point out that gamma rays and $\mathrm{X}$-rays behaved, in many respects, like uncharged particles: an idea with which modern quantum theory has now familiarized us. His remarkable work on the elucidation of crystalline structures by $\mathrm{X}$-rays, carried out in collaboration. with his son W. L. (now Sir Lawrence) Bragg, has founded a new branch of science, and has forged a new and valuable weapon in the armoury of industrial research. X-ray analysis is now being applied to the study and improvement of an amazing variety of commercial products.

As an interpreter of physics to the public Bragg was unrivalled in the present age. His discourses at the 
Royal Institution, illustrated with all the resources at its command, were a sheer delight. Simple yet profound, the non-scientific hearer could gather $a_{0}$ clear mental picture of the subject discussed, while the professional man of science enjoying the apparently effortless artistry of the presentation usually found that, in addition, he had gained some quite new side-lights on a subject with which he had thought himself completely familiar.

J. A. Crowther.

NeARLy twenty years ago, as a young graduate, I joined the team of research workers at University College, London, who were inspired and led by Sir William Bragg. His was a charming personality and he was an ideal research professor. Keen on his own work, bubbling over with enthusiasm at each new discovery; just as interested in ours, yet never obtrusive, never impatient. We knew that he shared our joy at each idea proved correct, because he himself had such an astonishing intuition. He knew where to look for knowledge ; but although intuition showed him the way, he was never satisfied with less than the most complete proof that the knowledge attained was fundamentally sound. An admitted mistake found him sympathetically understanding; like Faraday, he never regarded time as wasted if it increased experience. Yet he could be stern on occasion: a young man who spoke slightingly of one whose lifetime had been spent in determining one physical constant really accurately was most surprised to receive a sharp rebuke. Such painstaking and unspectacular labour Sir William knew to be the very cornerstone of research.

Sir William attracted and welcomed to the labora. tories of the Royal Institution workers from all parts of the world, and most of them must remember with gratitude not only the opportunities for scientific research and discussion thus afforded but also, and perhaps not least, the delightful garden parties given at his country cottage at Chiddingfold. Those of us who are still working on the problems that enthralled him to the last, feel that we have lost not only a leader but also a personal friend.

Kathleen Lonsdale.

\section{NEW FELLOWS OF THE ROYAL SOCIETY}

The following were elected to the fellowship of the Royal Society on March 19 :

ProF. J. H. BURN professor of pharmacology, Oxford, formerly dean of the College of the Pharmaceutical Society; distinguished for his work in physiology and pharmacology and on the principles and methods of biological standardization.

Dr. F. M. Burnet, assistant director of the Walter and Eliza Hall Institute for Medical Research, Melbourne ; distinguished for his researches in bacteriology, especially on avian and mammalian viruses.

Dr. M. Drxon, lecturer in biochemistry, Cambridge ; distinguished for his work on tissue respiration and respiratory catalysis.

Prof. E. C. Dodns, M.V.O., professor of biochemistry, Middlesex Hospital Medical School ; distinguished for his investigations in biochemistry in relation to physiology and medicine and especially in the synthetic production of œstrogenic agents.

Mr. A. FAGE, principal scientific officer, Aerodynamies Department, National Physical Laboratory; distinguished for his contributions to the experimental study of aero- and hydro-dynamics, particularly in relation to turbulent flow.

Colonel N. H. FaIrley, A.A.M.C., consulting physician in tropical diseases, director of special research, Hospital for Tropical Diseases, London; distinguished for his researches in tropical medicine.

Mr. P. HaLL, university lecturer in mathematics, Cambridge ; distinguished for his contributions to pure mathematics, particularly in the theory of groups.

Prof. G. H. Henderson, professor of mathematical physics, Dalhousie University, Halifax, Nova Scotia; distinguished for his work in radioactivity and particularly in the investigation of pleochroic haloes.

Prof. T. P. Hilditch, professor of industrial chemistry, Liverpool ; distinguished for his work on the chemistry of natural fats.

PROF. E. HrNDLE, regius professor of zoology, Glasgow ; distinguished for his work in parasitology, and on the cytology of artificial parthenogenesis.
Dr. C. S. Hanes, senior scientific officer, Low Temperature Research Station, Cambridge; distinguished for his researches in botany and biochemistry, especially the first enzymatic synthesis of starch.

Prof. A. Holmes, professor of geology, Durham ; distinguished for his work in petrology and the applications of radioactivity to geological problems.

Prof. D. M. NEwITT, assistant professor of chemical technology, Imperial College, London; distinguished for his work on high-pressure technology and for his researches on combustion.

Dr.C.C.Paterson, O.B.E., director of the Research Laboratories, General Electric Company, Wembley ; distinguished for his work in promoting physical and industrial research.

Dr. J. K. Roberts, assistant director of research, Colloid Science Laboratory, Cambridge; distinguished for his investigations by physical methods on adsorption and other surface phenomena of importance in catalysis.

Dr. H. W. B. Skinner, Wills research fellow and lecturer in spectroscopy, Bristol; distinguished for his work on the X-ray spectroscopy of the solid state, leading to results of importance in the theory of the structure of metals.

Prof. D. ThODAY, professor of botany, Bangor ; distinguished for his researches in plant physiology, particularly those dealing with photosynthesis, causal anatomy and the water relations of plants.

Prof. A. R. Todd, professor of chemistry, University of Manchester; distinguished for his researches in organic chemistry, notably the synthesis of vitamin $B_{1}$ and other natural compounds of physiological importance.

Prof. A. E. Trueman, professor of geology, Glasgow ; distinguished for his work in palæontology, particularly on molluscan faunas of the coal measures.

Mr. A. H. Wilson, university lecturer in mathematics, Cambridge; distinguished for his contributions to the electronic theory of solids and for his work on the properties of metals. 